\title{
RESERVOIR AGES IN EASTERN PACIFIC COASTAL AND ESTUARINE WATERS
}

\section{B. LYNN INGRAM}

Department of Geography, University of California, Berkeley, California 94720 USA

and

\section{JOHN R. SOUTHON}

Center for Accelerator Mass Spectrometry, L-397, Lawrence Livermore National Laboratory Livermore, California 94551 USA

\begin{abstract}
We have refined marine reservoir age estimates for eastern Pacific coastal waters with radiocarbon measurements of mollusk shells collected prior to 1950 . We have also investigated interspecific variability in ${ }^{14} \mathrm{C}$ ages for historic and
ancient shells from San Francisco Bay.
\end{abstract}

\section{INTRODUCTION}

Globally, ocean surface waters are depleted in radiocarbon content relative to the atmosphere by an amount equivalent to $400{ }^{14} \mathrm{C}$ yr. Regionally the oceans deviate from this value, reflecting variations in upwelling (Stuiver, Pearson and Braziunas 1986), freshwater inflow in coastal regions (Spiker 1980), and interhemispheric variations in atmospheric ${ }^{14} \mathrm{C}$ content (Stuiver and Braziunas 1993). Knowledge of the value of the regional deviation from the ocean reservoir age (or $\Delta R$ ) is necessary to accurately calibrate ${ }^{14} \mathrm{C}$ ages of marine materials. Since the $1950 \mathrm{~s}$, determination of $\Delta R$ values by surface water ${ }^{14} \mathrm{C}$ measurements has been precluded due to the artificially high ${ }^{14} \mathrm{C}$ activity in surface waters from nuclear testing. Thus, $\Delta R$ values in coastal waters must be determined indirectly from ${ }^{14} \mathrm{C}$ measurements of carbonate shells or other marine materials of known age collected prior to 1950.

Previous ${ }^{14} \mathrm{C}$ measurements of known-age mollusk shells indicate an average $\Delta \mathrm{R}$ for coastal California of $225 \pm 15 \mathrm{yr}$, for seven analyses (Berger, Taylor and Libby 1966; Robinson and Trimble 1981), corresponding to a significant ${ }^{14} \mathrm{C}$ depletion. This is attributed to upwelling of "old" Pacific Intermediate Water, driven by a divergence in surface ocean flow patterns created by winds blowing southward along the California coast (Dorman and Palmer 1980; Robinson 1980). Other studies suggest that the $\Delta \mathrm{R}$ values along the California coast are variable, with values as great as $500 \mathrm{yr}$ (Bouey and Basgall 1991). The $\Delta \mathrm{R}$ value has been shown to decrease from $185 \pm 20 \mathrm{yr}$ off Mexico (8 analyses), to $5 \pm 50 \mathrm{yr}$ in Central American and Equadorean waters (9 analyses), and to increase again to $190 \pm 40 \mathrm{yr}$ off Peru and northern Chile (3 analyses; Taylor and Berger 1967).

Due to the small number of samples, and large spatial and possibly temporal variability in upwelling in these coastal areas, more analyses are clearly necessary. So is characterization of the effects of other processes such as freshwater inflow, carbon recycling, and variable growth habits of marine organisms. In this study, we measured the ${ }^{14} \mathrm{C}$ ages of historically collected mollusk shells from coastal California, Mexico, Central America and Chile to better constrain the modern $\Delta \mathrm{R}$ values in these regions. In addition, ${ }^{14} \mathrm{C}$ ages of historically collected mollusks, as well as fossil mollusks separated from sediments cored in San Francisco Bay, were used to assess interspecific differences in reservoir ages in modern and ancient estuarine environments.

\section{METHODS}

Modern (pre-bomb) mollusk specimens used in this study were provided by the Museum of Paleontology at the University of California, Berkeley, and the Natural History Museum in Santa Barbara. 
Species used in the study are native oysters, clams and mussels (Ostrea lurida, Macoma balthica, Mytilus californianus and Mytilus edulis). In most cases, it is uncertain whether these specimens were collected live or not. These species were chosen because they commonly occur in archaeological coastal deposits (shellmounds) and geological sediments along coastal California (Fig. 1). They may also provide information about the causes of interspecific ${ }^{14} \mathrm{C}$ age differences.

In addition to historically collected material, we separated these same mollusk species from estuarine sediments cored in San Francisco Bay. Mollusks from the same stratigraphic level in the core were ${ }^{14} \mathrm{C}$-dated to determine differences in apparent ages between species that might be useful in assessing various processes leading to interspecies differences. This information is also useful in illustrating the range in ${ }^{14} \mathrm{C}$ ages obtainable from the same stratigraphic level in geological sediments using different carbonate shell material.

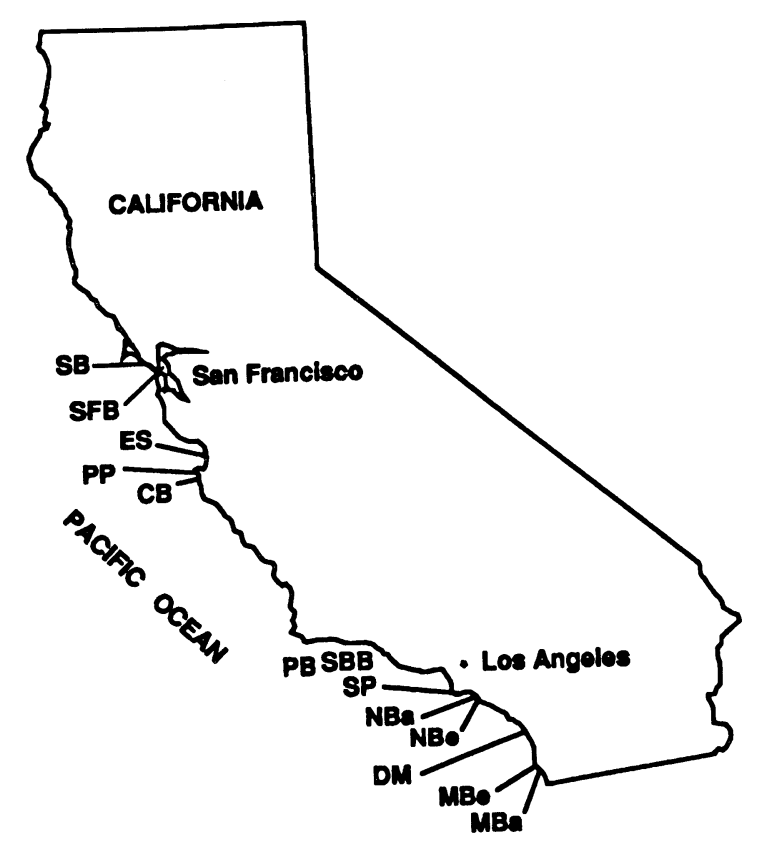

Fig. 1. California sampling locations for this study: $\mathrm{SB}=$ Stinson Beach; SFB = San Francisco Bay; ES = Elkhorn Slough; PP = Point Pinos; CB = Carmel Bay; PB = Pelican Bay; SBB = Santa Barbara Basin; SP = San Pedro; $\mathrm{NBa}=$ Newport Bay; $\mathrm{NBe}=$ Newport Beach; $\mathrm{DM}=\mathrm{Del}$ Mar; $\mathrm{MBe}=$ Mission Beach; $\mathrm{MBa}=$ Mission Bay.

\section{Radiocarbon Analysis}

Radiocarbon analyses were performed at the Center for Accelerator Mass Spectrometry, Lawrence Livermore National Laboratory (Davis et al. 1990). Shell samples (ca. $8 \mathrm{mg}$ of carbonate) were etched with $0.5 \mathrm{~N}$ hydrochloric acid and rinsed with deionized water. Carbonate samples were placed in a $10-\mathrm{ml}$ vacutainer (disposable blood sample vial), which was evacuated through the rubber stopper using a hypodermic needle. After evacuation to below $20 \mathrm{mtorr}, 0.5 \mathrm{ml}$ of phosphoric acid was added to the vacutainer with a syringe, and the sample was hydrolyzed for $30-60 \mathrm{~min}$ at $90^{\circ} \mathrm{C}$ to generate $\mathrm{CO}_{2}$. This was reduced to graphite using hydrogen with a cobalt catalyst (Vogel, Nelson and Southon 1987). ${ }^{14} \mathrm{C} /{ }^{13} \mathrm{C}$ ratios were measured by $\mathrm{AMS}$, and ${ }^{14} \mathrm{C}$ ages were determined following the conventions of Stuiver and Polach (1977) and Donahue, Linick and Jull (1990). 
TABLE $1 .{ }^{14} \mathrm{C}$ Ages on Known Age Mollusks

\begin{tabular}{|c|c|c|c|c|c|c|c|c|c|c|}
\hline $\begin{array}{l}\text { CAMS } \\
\text { no. }\end{array}$ & Sample & $\begin{array}{l}\text { Museum } \\
\text { no. }\end{array}$ & Date & $\begin{array}{l}\text { Location* } \\
\text { (lat//long.) }\end{array}$ & $\begin{array}{l}\delta^{13} \mathrm{C} \dagger \\
(\% 0)\end{array}$ & $\begin{array}{l}\mathrm{D}^{14} \mathrm{C} \\
(\% 0)\end{array}$ & $\begin{array}{l}\Delta^{14} \mathrm{C} \\
\left(\Phi_{0}\right)\end{array}$ & ${ }^{14} \mathrm{C}$ age & $\begin{array}{l}\text { Model } \\
\text { age }\end{array}$ & $\Delta \mathbf{R}$ \\
\hline \multicolumn{11}{|c|}{ San Francisco Bay Estuary } \\
\hline 15700 & Mytilus 4 & R-1776 & 1943 & $\begin{array}{l}\text { Pt. Richmond, } \\
\text { San Pablo Bay }\end{array}$ & -2 & $-107.3 \pm 5.9$ & $-101.5 \pm 6.2$ & $910 \pm 50$ & 477 & $435 \pm 53$ \\
\hline 15701 & Ostrea 1 & R-1776 & 1943 & $\begin{array}{l}38^{\circ} \mathrm{N}, 122.5^{\circ} \mathrm{W} \\
\text { Pt. Richmond, } \\
\text { San Pablo Bay }\end{array}$ & 0 & $-89.4 \pm 6.7$ & $-83.6 \pm 7.0$ & $705 \pm 60$ & 477 & $275 \pm 59$ \\
\hline 15702 & Macoma 15 & R-1776 & 1943 & $\begin{array}{l}38^{\circ} \mathrm{N}, 122.5^{\circ} \mathrm{W} \\
\text { Pt. Richmond, } \\
\text { San Pablo Bay } \\
38^{\circ} \mathrm{N}, 122.5^{\circ} \mathrm{W}\end{array}$ & $\mathbf{0}$ & $-98.8 \pm 9.0$ & $840 \pm 80$ & $477 \pm 80$ & 477 & $359 \pm 80$ \\
\hline 8139 & Mytilus & -- & 1939 & $\begin{array}{l}\text { San Francisco Bay } \\
37.7^{\circ} \mathrm{N}, 122.2^{\circ} \mathrm{W}\end{array}$ & -2 & $-111.5 \pm 10.7$ & $-105.2 \pm 10.9$ & $950 \pm 100$ & 474 & $476 \pm 97$ \\
\hline 8140 & Mytilus 18 & - & 1939 & $\begin{array}{l}\text { San Francisco Bay } \\
37.7^{\circ} \mathrm{N}, 122.2^{\circ} \mathrm{W}\end{array}$ & -2 & $-84.9 \pm 7.4$ & $-78.5 \pm 7.7$ & $710 \pm 60$ & 474 & $238 \pm 65$ \\
\hline 8141 & Mytilus 19 & - & 1939 & $\begin{array}{l}\text { San Francisco Bay } \\
37.7^{\circ} \mathrm{N}, 122.2^{\circ} \mathrm{W}\end{array}$ & -2 & $-94.4 \pm 7.4$ & $-88.1 \pm 7.7$ & $800 \pm 70$ & 474 & $322 \pm 66$ \\
\hline 8873 & Mytilus 20 & - & 1939 & $\begin{array}{l}\text { San Francisco Bay } \\
37.7^{\circ} \mathrm{N}, 122.2^{\circ} \mathrm{W}\end{array}$ & -2 & $-117.0 \pm 7.8$ & $-117.0 \pm 8.1$ & $1000 \pm 70$ & 474 & $526 \pm 71$ \\
\hline 18486 & Macoma 3 & R-1670 & 1899 & $\begin{array}{l}\text { San Francisco Bay } \\
37.7^{\circ} \mathrm{N}, 122.2^{\circ} \mathrm{W}\end{array}$ & -0.79 & $-88.2 \pm 5.3$ & $-82.0 \pm 5.7$ & $740 \pm 50$ & 467 & $275 \pm 47$ \\
\hline $\begin{array}{l}\text { Mean } \\
\text { Northern }\end{array}$ & & & & & & \multicolumn{4}{|c|}{ Northern California Coast } & $365 \pm 35$ \\
\hline $\begin{array}{l}\text { Northern } \\
16293\end{array}$ & $\begin{array}{l}n \text { California C } \\
\text { Macoma } 6\end{array}$ & R-1652 & 1936 & $\begin{array}{l}\text { Stinson Beach, } \\
\text { Marin Co. }\end{array}$ & 2 & $-155.4 \pm 4.1$ & $-148.7 \pm 4.6$ & $1360 \pm 40$ & 472 & $885 \pm 39$ \\
\hline 16295 & Mytilus 15 & 1652 & 1936 & $\begin{array}{l}37.9^{\circ} \mathrm{N}, 122.7^{\circ} \mathrm{W} \\
\text { Stinson Beach, } \\
\text { Marin Co. } \\
37.9^{\circ} \mathrm{N}, 122.7^{\circ} \mathrm{W}\end{array}$ & 0 & $-88.8 \pm 5.5$ & $-82.1 \pm 5.9$ & $750 \pm 50$ & 472 & $275 \pm 48$ \\
\hline 16296 & Ostrea 3 & 1652 & 1936 & $\begin{array}{l}\text { Stinson Beach, } \\
\text { Marin Co.,CA } \\
37.9^{\circ} \mathrm{N}, 122.7^{\circ} \mathrm{W}\end{array}$ & 2 & $-93.3 \pm 5.5$ & $-86.6 \pm 5.9$ & $790 \pm 50$ & 472 & $315 \pm 49$ \\
\hline 16294 & Macoma 12 & R-1755 & 1930 & $\begin{array}{l}\text { Elkhorn Slough, } \\
\text { Monterey Bay, } \\
36.8^{\circ} \mathrm{N}, 121.8^{\circ} \mathrm{W}\end{array}$ & 2 & $-102.7 \pm 5.4$ & $-97.3 \pm 5.8$ & $870 \pm 50$ & 467 & $403 \pm 48$ \\
\hline 18494 & Mytilus 12 & 1775 & 1939 & $\begin{array}{l}\text { Point Pinos, } \\
\text { Pacific Grove }\end{array}$ & -0.2 & $-85.4 \pm 5.9$ & $-79.1 \pm 6.2$ & $720 \pm 50$ & 474 & $243 \pm 52$ \\
\hline 18497 & Mytilus 16 & 1774 & 1939 & $\begin{array}{l}36.7^{\circ} \mathrm{N}, 121.9^{\circ} \mathrm{W} \\
\text { Carmel Bay, } \\
\text { Monterey } \\
36.6^{\circ} \mathrm{N}, 121.9^{\circ} \mathrm{W}\end{array}$ & 0.17 & $-82.3 \pm 6.0$ & $-75.9 \pm 6.3$ & $690 \pm 50$ & 474 & $216 \pm 53$ \\
\hline Mean (N & Macoma 6 om & nitted) & & & & & $-84.2 \pm 3.7$ & & & $290 \pm 35$ \\
\hline \multicolumn{11}{|c|}{ Santa Barbara Channel } \\
\hline & Mytilus & 43190 & 1936 & $\begin{array}{l}\text { Santa Barbara } \\
34.6^{\circ} \mathrm{N}, 119.7^{\circ} \mathrm{W}\end{array}$ & 0.29 & $-94.6 \pm 3.3$ & $-87.9 \pm 3.9$ & $800 \pm 30$ & 478 & $320 \pm 29$ \\
\hline$\ddagger$ & Mytilus & 431902 & 1936 & $\begin{array}{l}\text { Santa Barbara } \\
34.6^{\circ} \mathrm{N} 119.7^{\circ} \mathrm{W}\end{array}$ & 0.13 & $-87.2 \pm 6.3$ & $-80.5 \pm 6.6$ & $730 \pm 60$ & 478 & $255 \pm 55$ \\
\hline 16297 & Mytilus 9 & E-1064 & 1949 & $\begin{array}{l}\text { Pelican Bay, } \\
\text { Santa Cruz ls. } \\
34.1^{\circ} \mathrm{N}, 119.7^{\circ} \mathrm{W} \\
\text { Mean }\end{array}$ & 0 & $-72.7 \pm 4.8$ & $-62.6 \pm 5.2$ & $610 \pm 40$ & 482 & $124 \pm 42$ \\
\hline \multicolumn{11}{|c|}{ 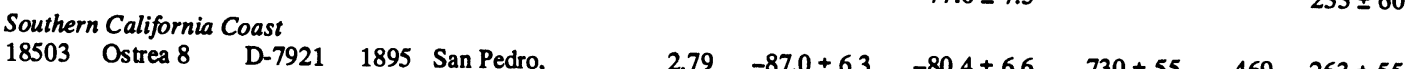 } \\
\hline 18503 & Ostrea 8 & D-7921 & 1895 & $\begin{array}{l}\text { San Pedro, } \\
\text { Los Angeles } \\
33.7^{\circ} \mathrm{N}, 118.2^{\circ} \mathrm{W}\end{array}$ & 2.79 & $-87.0 \pm 6.3$ & $-80.4 \pm 6.6$ & $730 \pm 55$ & 469 & $263 \pm 55$ \\
\hline 18501 & Ostrea 6 & E-6358 & 1948 & $\begin{array}{l}\text { Newport Bay, } \\
\text { Orange Co. } \\
33.6^{\circ} \mathrm{N}, 117.9^{\circ} \mathrm{W}\end{array}$ & 2 & $-101.4 \pm 5.9$ & $-91.2 \pm 6.2$ & $860 \pm 50$ & 481 & $378 \pm 53$ \\
\hline
\end{tabular}




\begin{tabular}{|c|c|c|c|c|c|c|c|c|c|c|}
\hline $\begin{array}{l}\text { CAMS } \\
\text { no. }\end{array}$ & Sample & $\begin{array}{c}\text { Museum } \\
\text { no. }\end{array}$ & Date ( & $\begin{array}{l}\text { Location* } \\
\text { (lat./long.) }\end{array}$ & $\begin{array}{c}\delta^{13} \mathrm{C} \dagger \\
(\% 0)\end{array}$ & $\begin{array}{l}\mathrm{D}^{14} \mathrm{C} \\
(\$ 0)\end{array}$ & $\begin{array}{l}\Delta^{14} \mathrm{C} \\
(\% 0)\end{array}$ & ${ }^{14} \mathrm{C}$ age & $\begin{array}{l}\text { Model } \\
\text { age }\end{array}$ & $\Delta \mathbf{R}$ \\
\hline 18502 & Ostrea 7 & E-6162 & 1948 & $\begin{array}{l}\text { Newport Bay, } \\
\text { Orange Co. } \\
33.6^{\circ} \mathrm{N}, 117.9^{\circ} \mathrm{W}\end{array}$ & 1.64 & $-998.0 \pm 0.8$ & - & $\begin{array}{l}49,990 \pm \\
3200\end{array}$ & - & - \\
\hline 18500 & Ostrea 5 & A-3991 & 1890 & $\begin{array}{l}\text { Newport Beach, } \\
\text { Orange Co } \\
33.6^{\circ} \mathrm{N}, 117.9^{\circ} \mathrm{W}\end{array}$ & 2.66 & $-131.0 \pm 6.7$ & $123.8 \pm 7.0$ & $1130 \pm 60$ & 471 & $657 \pm 62$ \\
\hline 16298 & Macoma 14 & A-3991 & 1890 & $\begin{array}{l}33.6^{\circ} \mathrm{N}, 117.9^{\circ} \mathrm{W} \\
\text { Newport Beach, } \\
\text { Orange Co } \\
33.6^{\circ} \mathrm{N}, 117.9^{\circ} \mathrm{W}\end{array}$ & 2 & $-139.5 \pm 4.8$ & $-132.3 \pm 5.2$ & $1210 \pm 45$ & 471 & $736 \pm 45$ \\
\hline 18487 & Macoma 10 & B-829 & 1939 & $\begin{array}{l}32.9^{\circ} \mathrm{N}, 117.3^{\circ} \mathrm{W} \\
\text { Mission Bay, } \\
\text { San Diego } \\
32.8^{\circ} \mathrm{N}, 117.2^{\circ} \mathrm{W}\end{array}$ & 1.64 & $-76.7 \pm 4.9$ & $-70.4 \pm 5.3$ & $640 \pm 40$ & 474 & $167 \pm 43$ \\
\hline 18493 & Mytilus 8 & E-6168 & 1948 & $\begin{array}{l}\text { Mission Bay, } \\
\text { San Diego } \\
32.8^{\circ} \mathrm{N}, 117.2^{\circ} \mathrm{W}\end{array}$ & -0.38 & $-81.2 \pm 5.2$ & $-70.9 \pm 5.6$ & $680 \pm 45$ & 481 & $199 \pm 45$ \\
\hline 18488 & Macoma 13 & R-1655 & 1938 & $\begin{array}{l}32.8^{\circ} \mathrm{N}, 117.2^{\circ} \mathrm{W} \\
\text { Mission Beach, } \\
\text { San Diego } \\
32.8^{\circ} \mathrm{N}, 117.3^{\circ} \mathrm{W}\end{array}$ & 2.64 & $-417.0 \pm 3.8$ & - & $4330 \pm 50$ & - & - \\
\hline 18498 & Ostrea 2 & 1655 & 1938 & $\begin{array}{l}\text { Mission Beach, } \\
\text { San Diego } \\
32.8^{\circ} \mathrm{N}, 117.3^{\circ} \mathrm{W}\end{array}$ & 2.71 & $-149.0 \pm 5.6$ & $-142.6 \pm 5.9$ & $1300 \pm 50$ & 473 & $823 \pm 53$ \\
\hline Mean (N & $\begin{array}{l}\text { Macoma 13, } 1 \\
\text { California }\end{array}$ & 14 \& Ostre & $2,5,7$ & 7 omitted) & & & $-74.3 \pm 4.6$ & & & $220 \pm 40$ \\
\hline $\begin{array}{l}\text { Gulf of C } \\
18489\end{array}$ & $\begin{array}{l}\text { California } \\
\text { Macoma } 16\end{array}$ & B-839 & 1940 & $\begin{array}{l}\text { Miramar Beach, } \\
\text { Guaymas, Mexico } \\
28^{\circ} \mathrm{N}, 111^{\circ} \mathrm{W}\end{array}$ & 1.82 & $-101.7 \pm 5.9$ & $-95.5 \pm 6.2$ & $860 \pm 50$ & 475 & $387 \pm 53$ \\
\hline 18499 & Ostrea 4 & A-3646 & 1940 & $\begin{array}{l}\text { Carmen Is., } \\
\text { Baja, Mexico } \\
26^{\circ} \mathrm{N}, 110^{\circ} \mathrm{W}\end{array}$ & 2.86 & $-107.3 \pm 6.2$ & $-101.0 \pm 6.5$ & $910 \pm 60$ & 475 & $436 \pm 56$ \\
\hline $\begin{array}{l}\text { Central } \\
18491\end{array}$ & $\begin{array}{l}\text { America } \\
\text { Macoma } 18\end{array}$ & S-78 & 1932 & $\begin{array}{l}\text { San Jose de Guate, } \\
\text { Guatemala } \\
14.0^{\circ} \mathrm{N}, 90.9^{\circ} \mathrm{W}\end{array}$ & 1.83 & $-80.8 \pm 6.0$ & $-75.6 \pm 6.3$ & $680 \pm 50$ & 469 & $208 \pm 52$ \\
\hline 18492 & Mytilus 3 & R-1659 & 1938 & $\begin{array}{l}\text { Gulf of Fonseca, } \\
\text { Honduras } \\
13.2^{\circ} \mathrm{N}, 87.6^{\circ} \mathrm{W}\end{array}$ & -0.41 & $-75.8 \pm 6.3$ & $-69.4 \pm 6.6$ & $630 \pm 50$ & 473 & $160 \pm 55$ \\
\hline & Macoma 17 & A-4010 & 1939 & $\begin{array}{l}\text { Corinto, Nicaragua } \\
12.5^{\circ} \mathrm{N}, 87.2^{\circ} \mathrm{W}\end{array}$ & 1.62 & $-88.5 \pm 5.9$ & & $740 \pm 50$ & 472 & \\
\hline Mean & & & & & & & $-75.7 \pm 3.7$ & & & $215 \pm 30$ \\
\hline $\begin{array}{l}17919 \\
17992\end{array}$ & Mytilus 2 & R-1763 & 1939 & $\begin{array}{l}\text { Valparaiso, Chile } \\
33.1^{\circ} \mathrm{S}, 71.8^{\circ} \mathrm{W}\end{array}$ & 1.98 & $-62.4 \pm 6.1$ & $-56.0 \pm 6.4$ & $520 \pm 50$ & 474 & $43 \pm 52$ \\
\hline $\begin{array}{l}\text { Southern } \\
17918\end{array}$ & $\begin{array}{l}\text { n Chile } \\
\text { Mytilus1 }\end{array}$ & R-1766 & 1939 & $\begin{array}{l}\text { Puerto Natales, } \\
\text { Chile } \\
51.7^{\circ} \mathrm{S}, 72.5^{\circ} \mathrm{W}\end{array}$ & -2.32 & $-80.8 \pm 4.7$ & $-74.4 \pm 5.1$ & $680 \pm 40$ & 474 & $203 \pm 41$ \\
\hline
\end{tabular}

*All locations are in California unless otherwise noted $+\delta^{13} \mathrm{C}$ values shown as single digits are estimated $\ddagger$ Mean of several determinations 


\section{RESULTS AND DISCUSSION}

Radiocarbon ages for modern shell samples are listed in Table 1 , together with ${ }^{14} \mathrm{C}$ depletions $\left(\Delta^{14} \mathrm{C}\right)$ and $\Delta R$ values. Data from this work, and from previous studies compiled by Stuiver, Pearson and Braziunas (1986) are shown in Figure 2. Ages of fossil mollusk shells from San Francisco Bay sediment cores are listed in Table 2 (see also Fig. 3). The $\Delta^{14} \mathrm{C}$ values for the modern shells were corrected for the ${ }^{14} \mathrm{C}$ decay that occurred between the growth year (collection year) and 1950, and for the input to the oceans of ${ }^{14} \mathrm{C}$-depleted fossil-fuel carbon. We have used ${ }^{14} \mathrm{C}$ data from banded corals (Druffel and Suess 1983), and the calculations of Stuiver, Pearson and Braziunas (1986), to correct for this fossil-fuel influence. $\Delta R$ values were calculated by comparing global marine surface ages from an ocean model (Stuiver and Braziunas 1993) with the measured ${ }^{14} \mathrm{C}$ ages. We have calculated regional means from our $\Delta R$ data, but these should be used cautiously, since there may be inherent variability in $\Delta R$ in some of the areas studied (see below). In addition, because it was not certain which of the samples were collected live, those samples with unusually high $\Delta R$ values were assumed to have been reworked, and thus were not used in calculating the mean $\Delta R$ values.

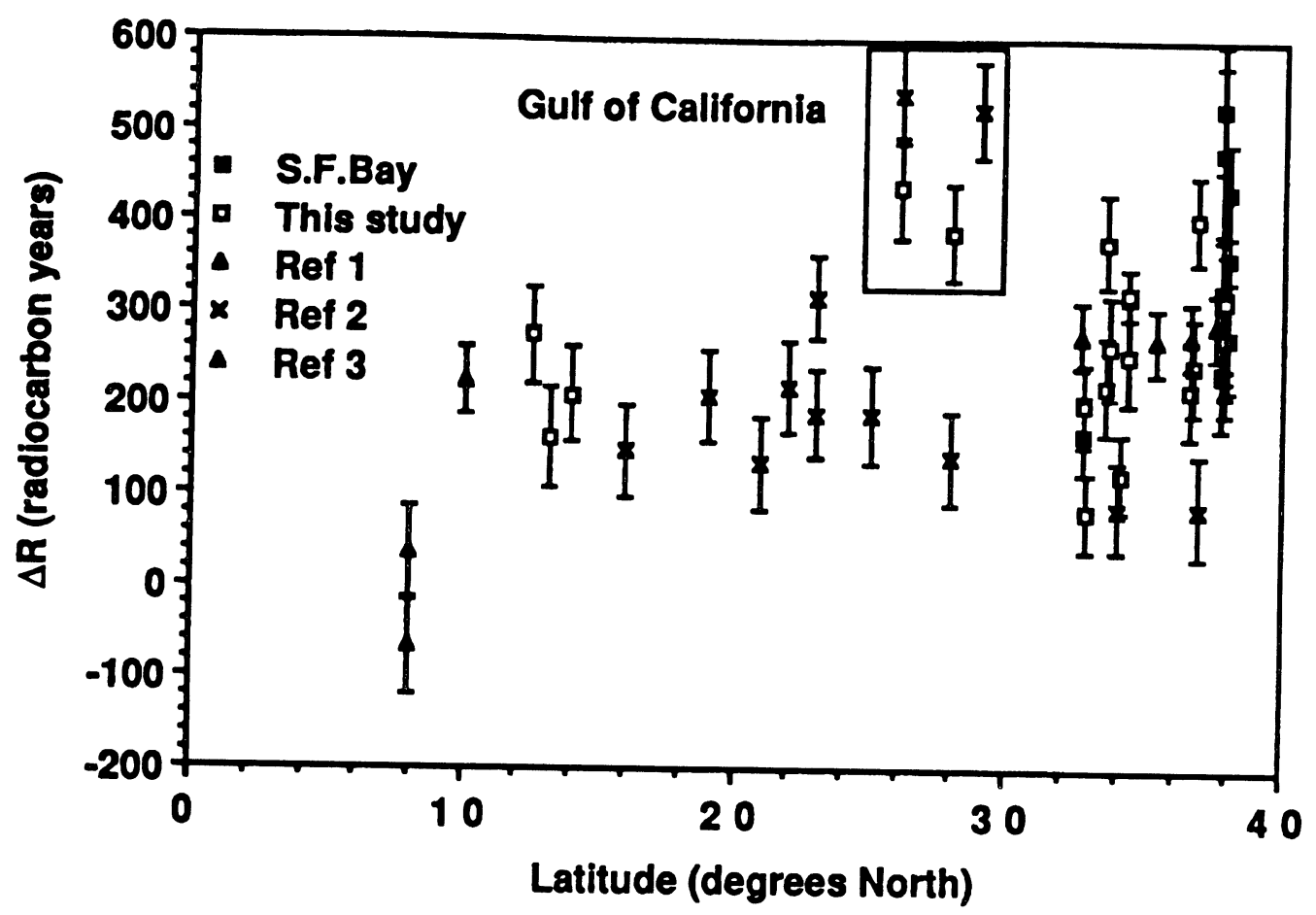

Fig. 2. $\Delta \mathrm{R}$ results from this investigation compared with those from three previous studies. San Francisco Bay data are plotted separately, since these waters are strongly influenced by river input. Ref 1: Robinson and Trimble (1980); Ref 2: Berger, Taylor and Libby (1966); Ref 3: Taylor and Berger (1967).

\section{Modern Shells and Eastern Pacific Reservoir Ages}

The coastal samples from Northern California show large reservoir ages (low $\Delta^{14} C$ ), due to intense upwelling in this region. The estuarine $\Delta^{14} \mathrm{C}$ values from San Francisco Bay are generally lower than those of the coastal samples. There is a large input of freshwater to the estuary from the Sacramento-San Joaquin River system, producing salinities as low as 10-20\%o in Bay waters, and our results suggest that pre-bomb 
freshwater entering the Bay was significantly depleted in ${ }^{14} \mathrm{C}$. Recent measurements of ${ }^{14} \mathrm{C}$ in Sacramento River water show $\Delta^{14} \mathrm{C}$ values $70 \%$ below those of the post-bomb atmosphere, and groundwater ${ }^{14} \mathrm{C}$ activities near the Sacramento River are ca. $65 \mathrm{pMC}$ (L. Davisson, LLNL, personal communication).

TABLE 2. ${ }^{14} \mathrm{C}$ Ages for Mollusks from San Francisco Bay Sediment Cores

\begin{tabular}{lccc}
\hline \multicolumn{3}{l}{$\begin{array}{l}\text { Dediment } \\
\text { (cm) }\end{array}$} & \multicolumn{3}{c}{ Macoma } & Mytilus & Ostrea \\
\cline { 2 - 4 }$C P-1$ & & & \\
173 & $1910 \pm 220$ & -- & $960 \pm 120$ \\
$C P-2$ & & & \\
453 & $4680 \pm 80$ & -- & $4540 \pm 70$ \\
$C P-3$ & & & \\
9 & $2540 \pm 70$ & -- & $3210 \pm 60$ \\
65 & $3650 \pm 60$ & -- & $4160 \pm 60$ \\
86 & $3610 \pm 70$ & -- & $4280 \pm 60$ \\
133 & $3680 \pm 70$ & -- & $5040 \pm 60$ \\
143 & $4110 \pm 60$ & -- & $4520 \pm 60$ \\
161 & $4200 \pm 70$ & -- & $4860 \pm 60$ \\
$O P-1$ & & & \\
5 & $750 \pm 60$ & $1650 \pm 60$ & \\
29 & $1110 \pm 60$ & $1700 \pm 70$ & $1090 \pm 70$ \\
57 & $1410 \pm 60$ & $1890 \pm 70$ & $900 \pm 70$ \\
65 & $730 \pm 70$ & $1830 \pm 100$ & \\
402 & $3310 \pm 70$ & $3760 \pm 70$ & \\
523 & $5070 \pm 60$ & $4850 \pm 90$ & \\
$O P-2$ & & & \\
257 & $1310 \pm 60$ & $1110 \pm 70$ & \\
740 & $6270 \pm 60$ & $6200 \pm 70$ & \\
\hline
\end{tabular}

The data in Figure 2 suggest an increase in $\Delta \mathrm{R}$ for coastal California waters of 50-100 $\mathrm{yr}$ at ca. 33$34^{\circ} \mathrm{N}$ latitude. This is plausible on oceanographic grounds, because the coastline trends sharply eastward below Pt. Conception at the western end of the Santa Barbara Basin (see Fig. 1). For much of the year, the California Current continues on a more southerly course, and the Southern California Bight to the southeast is occupied by a northward-flowing countercurrent. Coastal waters to the south are less subject to upwelling, and are less influenced by the southward advection of water from the strong upwelling regions further north (Dorman and Palmer 1980).

A feature of the southern California data was the high proportion of outliers. Six of the 11 samples gave results consistent with those of Berger, Taylor and Libby (1966), but two samples (Macoma13 and Ostrea-7) were clearly reworked, and three others gave $\Delta \mathrm{R}$ values of $c a .700 \mathrm{yr}$. We have tentatively assumed that these are also reworked and have excluded them from calculation of the regional mean $\Delta R$. The five outliers are from, or adjacent to, estuaries (Newport Bay and Mission Bay) and could possibly result from reworking during flood events, if some of this material were redeposited on nearby oceanfront beaches. Erosion from uplifted beach bluff deposits is another possible mechanism for producing reworked material. 
The presence of these samples in the museum collections may be an indicator that reworked specimens are relatively common in some California beach deposits. If this is true, it suggests that the probability of error in dating natural shell deposits is high, unless multiple samples are dated to reveal the presence of reworked material. Midden samples, which were collected live, would not be subject to this difficulty. If estuarine reworking is involved, choosing only open-ocean species may reduce the likelihood of error. Note, however, that reworking is not the only possible explanation for high mollusk reservoir ages. Dye (1994) has shown that ${ }^{14} \mathrm{C}$ ages for limpet, cowrie and gastropod species found on Pleistocene limestone substrates in Hawaii are significantly older than those for specimens found on lava, and the likely effect on shell ages of dissolved geologic carbonate in river water has long been recognized (Berger, Taylor and Libby 1966).

The high $\Delta \mathrm{R}$ values from the Gulf of California samples are consistent with previous data (Berger, Taylor and Libby 1966) and with expectations for this known region of strong upwelling (Schrader et al. 1980). The Central American data agree with previous results (Berger, Taylor and Libby 1966; Taylor and Berger 1967), which show $\Delta \mathrm{R}$ relatively constant with latitude, down to $10^{\circ} \mathrm{N}$ (Fig. 2). Below that latitude, coastal waters as far south as the Galapagos are strongly influenced by equatorial water masses that are better equilibrated with the atmosphere than the waters of the California Current system further north. A sample from far southern Chile shows a larger $\Delta R$ than a specimen from Valparaiso, suggesting a stronger influence of ${ }^{14} \mathrm{C}$-depleted Southern Ocean water on the former. This is consistent with a previous study in the Beagle Channel, Tierra del Fuego (Albero, Angiolini and Piana 1986), which also showed large reservoir ages.

\section{San Francisco Bay Mollusks}

The results from in and around San Francisco Bay show that the natural variability in ${ }^{14} \mathrm{C}$ ages is much greater than the analytical uncertainty associated with the measurements. Three species of mollusk collected from Stinson Beach, just outside the Bay, reveal that the ${ }^{14} \mathrm{C}$ age of carbonate collected at the same time in the same environment may not necessarily have the same age. Ages of coexisting mollusks collected in 1936 differ by several hundred years, with a Macoma shell (reworked?) having the oldest age. Perhaps more significantly, modern mussels (Mytilus californianus), collected in 1939 from the central part of the Bay, show a spread of almost $300 \mathrm{yr}$. The mean $\Delta \mathrm{R}$ of $375 \mathrm{yr}$ in Table 1 thus represents a modern average value for San Francisco Bay, but wide variations about this mean are present.

Fossil mollusk shells from San Francisco Bay sediment cores show large differences in ${ }^{14} \mathrm{C}$ activity between mollusk types from the same stratigraphic level. For example, in core CP-3, taken in the south-central part of San Francisco Bay, Ostrea lurida is consistently older than Macoma balthica, by an average of $900{ }^{14} \mathrm{C}$ yr (Table 2; Fig. 3), but a single Ostrea sample from core CP-1 is younger than the Macoma shell. In core OP-1, Mytilus edulis is consistently older than Macoma by 450$1100 \mathrm{yr}$ (six samples), whereas in OP-2 Mytilus is younger than Macoma by 70-220 yr (two samples). This variability in the species age offsets between cores (while age offsets are generally systematic within individual cores) suggests that several factors may contribute to the ${ }^{14} \mathrm{C}$ age differences we observe.

One possible influence is the life habitat of the mollusk species. Clams, which are infauna, burrow into the sediment, to a depth of 5-15 cm. In contrast, oysters and mussels are epifaunal, living close to the sediment-water interface. Thus, oyster and mussel fossils from the same stratigraphic level would be expected to have an older age than coexisting clams. In most (but not all) cases, the data in Table 2 do show Macoma having the youngest ages. However, in core CP-3 (Fig. 3), for example, 
the age differences of 400-1400 yr correspond to depth differences of 30-110 cm, an order of magnitude deeper than clams actually live.

Another factor may be the effect of different feeding modes. Oysters and mussels obtain carbon directly from the water from phytoplankton. Macoma also feeds on surface deposits, deriving carbon not only from phytoplankton and phytobenthos, but from other sources such as river-borne organic detritus, decaying vascular plants transported from marshes, and microbes in the sediment (Nichols and Pamatmat 1988). Tanaka, Monaghan and Rye (1986) have shown that 23-85\% of the carbon incorporated into shell carbonate of mollusks is metabolic. No studies to date have evaluated the relative sources of carbon to mollusks in San Francisco Bay. However, a feeding preference for river-borne vascular plant debris or other terrestrial organic matter, which could have a young ${ }^{14} \mathrm{C}$ age relative to the coastal ocean, might give a younger age for some mollusk shells.

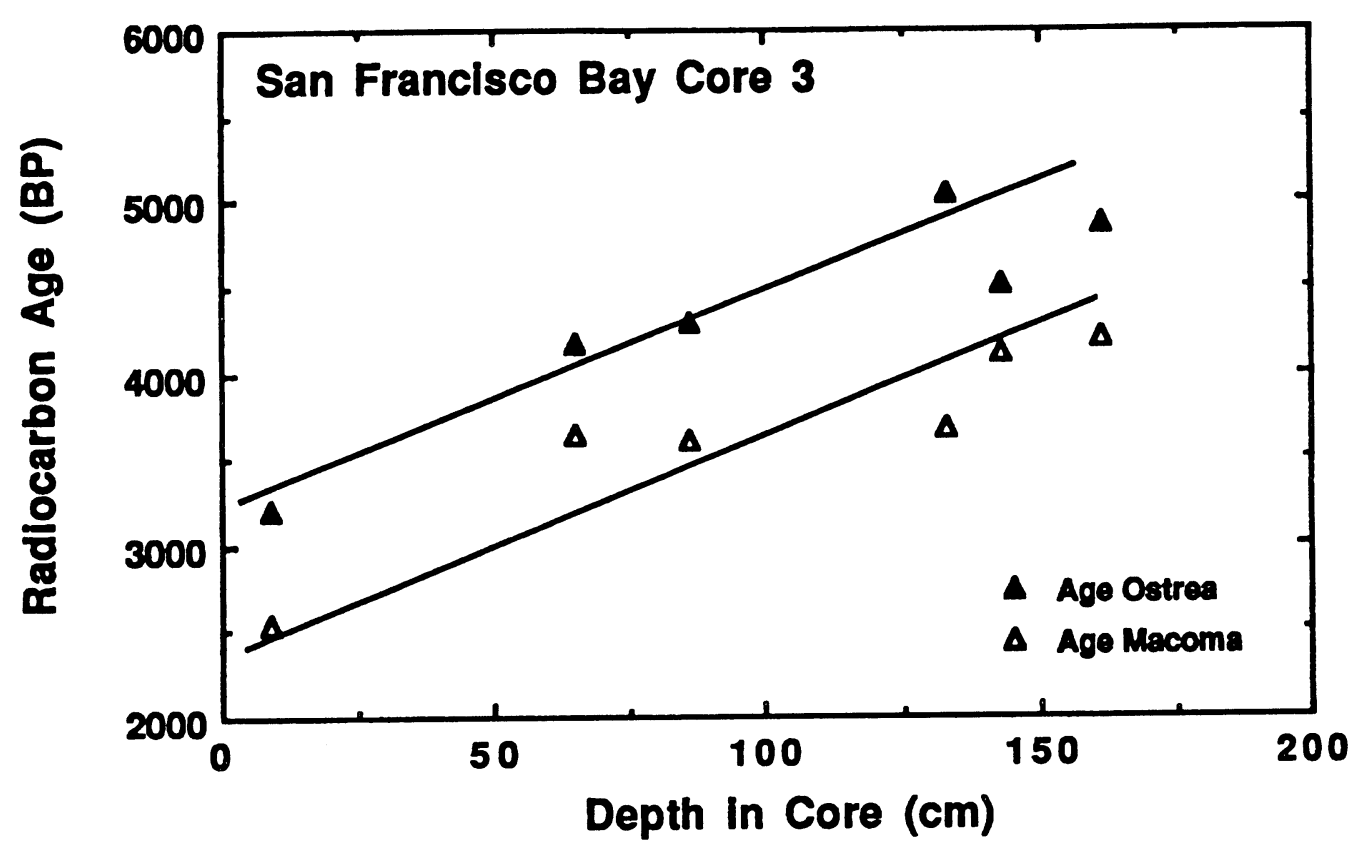

Fig. 3. ${ }^{14} \mathrm{C}$ ages for oysters (Ostrea lurida) and clams (Macoma balthica) from sediment core CP-3 from south San Francisco Bay

A third possible explanation for age variations is seasonal differences in growth. Post-bomb measurements by Robinson (1980) showed seasonal swings of up to $130 \%$ in the $\Delta^{14} \mathrm{C}$ of California coastal surface waters. Allowing for the reduced atmosphere-surface-deepwater ${ }^{14} \mathrm{C}$ gradient in prebomb times, seasonal variations of up to $30 \%$ seem plausible. Upwelling off California occurs during the late spring to early summer. Studies of the growth rates of Macoma in San Francisco Bay indicate that the clam grows much of its shell during the spring and fall (Nichols and Thompson 1982; Thompson and Nichols 1988), implying that it may have an older apparent age than a mollusk species that grew primarily in winter. However, because no comparable studies have been done with oysters or mussels in San Francisco Bay, the apparent age of Macoma relative to these other mollusks cannot be assessed. Note that this mechanism does not just apply in San Francisco Bay: seasonality of mollusk growth rates in a variable upwelling environment could contribute to the variability of coastal reservoir ages as well. 


\section{Conclusion}

We have refined reservoir ages and $\Delta R$ values of eastern Pacific coastal waters with ${ }^{14} \mathrm{C}$ measurements on mollusk shells collected prior to 1950 . Our results are generally in agreement with data from previous studies, and are consistent with known patterns of ocean circulation. The highest $\Delta R$ values are found in the Gulf of California, and $\Delta R$ increases toward the northern California coast: both are areas of strong upwelling. Data from two estuaries and nearby beaches in southern California included several outliers. The spurious ${ }^{14} \mathrm{C}$ ages may have resulted from processes such as reworking of mollusk shells during, e.g., storms or flood events. Thus, particular care may be required in using shell for dating California geological coastal deposits. Other dating problems may arise because reservoir ages from areas of seasonal upwelling, or from boundaries between different ocean circulation regimes, may vary significantly on seasonal, interannual, or longer time scales.

Evidence of serious problems in the dating of mollusks from estuaries is given by the San Francisco Bay results. Known-age Mytilus edulis from a single location in the Bay showed an age spread of almost $300 \mathrm{yr}$; and Mytilus, Macoma and Ostrea shells separated from the same level in sediment cores gave highly discrepant results, with age offsets as high as 1400 yr. Possible mechanisms for these variations include differences in habitat and feeding patterns, and the effects of seasonal changes in growth rates coupled with temporal upwelling and freshwater inflow variations. The variability in the results from different sediment cores within the Bay suggests that the causes are complex.

\section{ACKNOWLEDGMENTS}

Part of this work was performed under the auspices of the Department of Energy at the Lawrence Livermore National Laboratory under contract W-7405-Eng-48. B.L.I. was supported in part by an appointment to the Global Change Distinguished Postdoctoral Fellowship program, sponsored by the U.S. Department of Energy, Office of Health and Environmental Research, and administered by the Oak Ridge Institute for Science and Education. We thank Doug Kennett and Zoe Knesl for assistance with sample collection.

\section{REFERENCES}

Albero, M. C., Angiolini, F. E. and Piana, E. L. 1986 Discordant ages related to reservoir effect of archaeologic remains from the Tunel site, Beagle Channel, Argentine Republic. In Stuiver, M. and Kra, R. S., eds., Proceedings of the 12 th International ${ }^{14} \mathrm{C}$ Conference. $R a$ diocarbon 28(2A): 748-753.

Berger, R., Taylor, R. E. and Libby, W. 1966 Radiocarbon content of marine shells from the California and Mexican west coast. Science 153: 864-866.

Bouey, P. D. and Basgall, M. E. 1991 Archaeological patterns along the south-central coast, Point Piedras Blancas, San Luis Obispo County, California. California Department of Transportation 05-SLO-1: 39-48.

Davis, J. C., Proctor, I. D., Southon, J. R., Caffee, M. W., Heikkinen, D. W., Roberts, M. L., Moore, T. L., Turtletaub, K. W., Nelson, D. E., Loyd, D. H. and Vogel, J. S. 1990 LLNL/UC AMS facility and research program. In Proceedings of the 5th International Conference on Accelerator Mass Spectrometry. Nuclear Instruments and Methods B52(3,4): 269-272.
Donahue, D. J., Linick, T. W. and Jull, A. J. T. 1990 Isotope-ratio and background corrections for accelerator mass spectrometry radiocarbon measurements. $R a$ diocarbon 32(2): 135-142.

Dorman, C. E. and Palmer, D. P. 1980 Southern California summer coastal upwelling. In Richards, F. A., ed., Coastal Upwelling. Washington, D.C., American Geophysical Union: 44-56.

Druffel, E. R. M. and Suess, H. A. 1983 On the radiocarbon record in banded corals: Exchange parameters and net transport of $\mathrm{CO}_{2}$ between atmosphere and surface ocean. Journal of Geophysical Research 88: 12711280.

Dye, T. 1994 Apparent ages of marine shells: Implications for archaeological dating in Hawai'i. Radiocarbon 36(1): 51-57.

Nichols, F. G. and Pamatmat, M.M. 1988 The ecology of the soft-bottom benthos of San Francisco Bay: A community profile. U.S. Fish and Wildlife Service Biology Report 85(7.19): 73 p. 
Nichols, F. H. and Thompson, J. K. 1982 Seasonal growth in the bivalve Macoma balthica near the southern limit of its range. Estuaries 5: 110-120.

Robinson, S. W. 1980 Natural and man-made radiocarbon as a tracer for coastal upwelling processes. In Richards, F. A., ed., Coastal Upwelling. Washington, D.C., American Geophysical Union: 298-302.

Robinson, S. W. and Trimble, D. 1981 US Geological Survey Menlo Park, California, radiocarbon measurements II. Radiocarbon 23(2): 305-321.

Schrader, H., Kelts, K., Curray, J., Moore, D., Aguayo, E., Aubrey, M. P., Einsele, G., Fornari, D., Gieskes, J., Kastner, M., Lyle, M., Matoba, Y., Molina-Cruz, A., Niemitz, J., Rueda, J., Saunders, A., Simoneit, B. and Vaquier, V. 1980 Laminated diatomaceous sediments from the Guaymas basin slope (central Gulf of California): 250,000 year climate record. Science 207: 1207-1209.

Spiker, E. C. 1980 The behavior of ${ }^{14} \mathrm{C}$ and ${ }^{13} \mathrm{C}$ in estuarine water: Effects of in situ $\mathrm{CO}_{2}$ production and atmospheric exchange. Radiocarbon 22(3): 647-654.
Stuiver, M. and Braziunas, T. F. 1993 Modeling atmospheric ${ }^{14} \mathrm{C}$ influences and ${ }^{14} \mathrm{C}$ ages of marine samples to 10,000 BC. Radiocarbon 35(1): 137-189.

Stuiver, M., Pearson, G. W. and Braziunas, T. 1986 Radiocarbon age calibration of marine samples back to 9000 cal yr BP. Radiocarbon 28(2B): 980-1021.

Stuiver, M. and Polach, H. A. 1977 Discussion: Reporting of ${ }^{14} \mathrm{C}$ data. Radiocarbon 19(3): 355-363.

Tanaka, N., Monaghan, M. C. and Ry, D. M. 1986 Contribution of metabolic carbon to mollusc and barnacle shell carbonate. Nature 320: 520-523.

Taylor, R. E. and Berger, R. 1967 Radiocarbon content of marine shells from the Pacific coasts of Central and South America. Science 158: 1180-1182

Thompson, J. K. and Nichols, F. H. 1988 Food availability controls seasonal cycle of growth in Macoma balthica (L.) in San Francisco Bay, California. Journal of Experimental Biology and Ecology 116: 43-61.

Vogel, J. S., Nelson, D. E. and Southon, J. R. $1987{ }^{14} \mathrm{C}$ background levels in an accelerator mass spectrometry system. Radiocarbon 29(3): 323-333. 